\title{
Quantitative Use of Satellite Vidicon Data for Delimiting Sea Ice Conditions
}

\author{
E. PAUL McCLAIN ${ }^{1}$
}

\begin{abstract}
Although television pictures from Earth satellites have been used for over ten years to detect major sea ice features, direct photo-interpretation methods have been supplemented with a fully-automated technique employing Composite Minimum Brightness (CMB) charts. Lack of on-board calibration has prevented quantitative use of the CMB method. In a newly-developed procedure the satellite brightness measurements taken over selected areas are used for external calibration. The calibrated data were used to study sea ice conditions in the North American Arctic. Characteristic brightness levels were found corresponding to the following: 1) compact or very close pack, snow covered; 2) compact or very close pack, without snow but with little or no puddling; 3 ) very close to close pack with much puddling; 4) open pack, generally with much puddling and rotten ice; 5) very open pack or ice-free conditions.
\end{abstract}

RÉSUMÉ: Utilisation quantitative des données télévisées par satellite pour délimiter les conditions de la glace de mer. Bien qu'on utilise depuis plus de dix ans les images télévisées de satellites terrestres pour détecter les caractéristiques majeures de la glace de mer, on a complété ces méthodes de photo-interprétation directe par une technique entièrement automatique utilisant des tableaux de luminosité minimale composite (Composite Minimum Brightness, CMB). L'absence de calibration à bord du satellite empêchait l'utilisation quantitative de cette méthode dite CMB. Dans un procédé récemment mis au point, les mesures de luminosité prises par le satellite sur des aires choisies servent à la calibration externe. Les données ainsi calibrées ont servi à l'étude des conditions de la glace de mer dans l'Arctique nordaméricain. On a pu déterminer des niveaux caractéristiques de luminosité pour les cas suivants: 1) pack compact ou très fermé, couvert de neige; 2) pack compact ou très fermé, sans neige, avec peu ou pas de mares de fonte; 3) pack, de très fermé à fermé, avec beaucoup de mares de fonte; 4) pack ouvert, généralement avec beaucoup de mares de fonte et de glace pourrie; 5) pack très ouvert ou absence de glace.

РЕЗЮМЕ. Количественभый метод использования телеизображений со спутников для характеристики ледовитости моря. Телеизображения, принятые со спутников Земли, уже более 10 лет используются для получения характеристик ледовой обстановки на морях. При этом непосредственное дешифрирование изображений дополняется анализом специальных карт, отражающих уровень Составной Минимальной Яркости (СМЯ). Этот анализ может быть полностью автоматизирован, однако в виду того, что бортовые приемники не тарировались, он не позволял получать количественных характеристик ледовитости. Теперь методика "внешнего " тарирования телекамер разработана; она состоит в спутниковых измерениях яркости, выполненных над специально избранными участками поверхности моря. Стало вовможным испольвовать телеизображения, принятые со спутников, для получения количественных данных о ледовой обстановке в Северо-Американской Арктике. Установлено, что определенным характерным уровням яркости соответствуют следующие степени ледовитости: 1) паковый лед - сплошной или очень плотный, несущий снежный покров; 2) паковый лед - сплошной или очень плотный, без снега, но и без луж талой воды; 3) паковый лед - очень плотный до плотного, с обильными лужами; 4) разреженный пак с обильными лужами и участками разрупающегося льда; 5) очень разреженный пак или свободное от льдов море.

${ }^{1}$ National Oceanic and Atmospheric Administration, Hillcrest Heights, Maryland, U.S.A. 


\section{INTRODUCTION AND BACKGROUND}

Comprehensive and repetitive survey of polar ice fields would be of great benefit to atmospheric, marine, and other environmental scientists, as well as to commercial operations; polar-orbiting satellites could provide the necessary rapid and economical means of obtaining the much needed information.

The potential of meteorological satellite data for mapping ice fields was quickly recognized after the first pictures from TIROS and Nimbus experimental satellites became available (Wark and Popham 1962; Popham and Samuelson 1965). After the ESSA satellite system became fully operational in 1966, and when many countries at high latitudes began receiving pictures of their own areas directly from the Automatic Picture Transmission (APT) camera system, ice reconnaissance with the aid of satellite pictures became increasingly widespread (Bowley 1969; Potocsky 1968; Canada Meteorological Branch 1969; Aber and

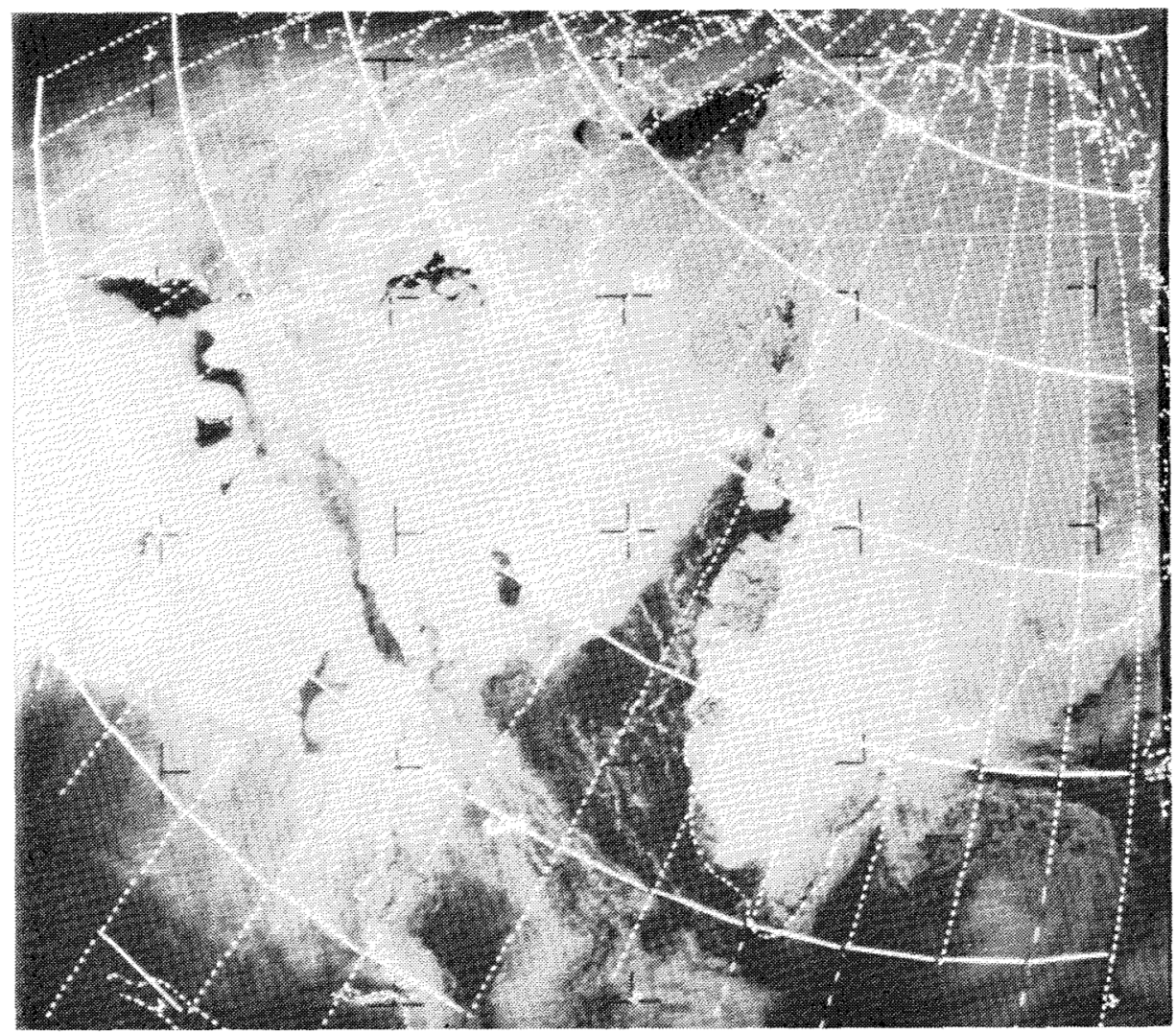

FIG. 1. Vidicon picture taken by ESSA 9 on 29 May 1970. Sea ice is visible in northern Hudson Bay, Foxe Basin, Hudson Strait, Baffin Bay, and the east coast of Greenland. Dark areas indicative of ice-free, very open pack, or new ice conditions are evident in numerous places; for example: northwest coastal area and south of Southampton and Coats Islands in Hudson Bay, southern Ungava and Frobisher Bays, and in Smith Bay between Ellesmere Island and northern Greenland. Changes in cloudiness from day to day enable discrimination between clouds and ice. 
Vowinckel 1972). The U.S.S.R. also is using its own and U.S.A. satellite data for sea ice surveys (Vasil'ev 1968). Although the techniques used most widely are those of photo-interpretation applied to individual television pictures (Fig. 1) on successive days, with the development of satellite picture digitization and rectification methods (Bristor et al. 1966), computer production of picture mosaics, averaging, compositing, and other data manipulation has become increasingly routine (Booth and Taylor 1969). Multiday, Composite Minimum Brightness (CMB) charts have been shown to be an effective tool for mapping of snow and ice boundaries from satellite video data (McClain and Baker 1969; McClain and Baliles 1971). Since October 1968 hemispheric 5-day CMB charts have been produced in the form of black-and-white mapped imagery at mesoscale $(55 \mathrm{~km}$.) resolution (Fig. 2). Augmented resolution CMB charts at $5.5 \mathrm{~km}$. resolution were produced experimentally for North America, the Arctic, and the Antarctic during limited periods in 1969 and 1970 (Fig. 3).

The CMB chart is one of the end products of a series of complex data processing steps requiring a high-speed electronic computer. After digitization of the analog video signal from the satellite, the raw data are brightness-normalized for nonlinearities in the response of the camera system and inequalities in solar illumination. The data are then mapped onto a polar stereographic map projection after overlapping imagery from adjacent orbits has been cropped. The original brightness (relative) scale of $0-63$ is compressed to $0-14$ during this process. The brightness values are then composited over a selected period of days by saving for final display only the minimum value found at each map posi-

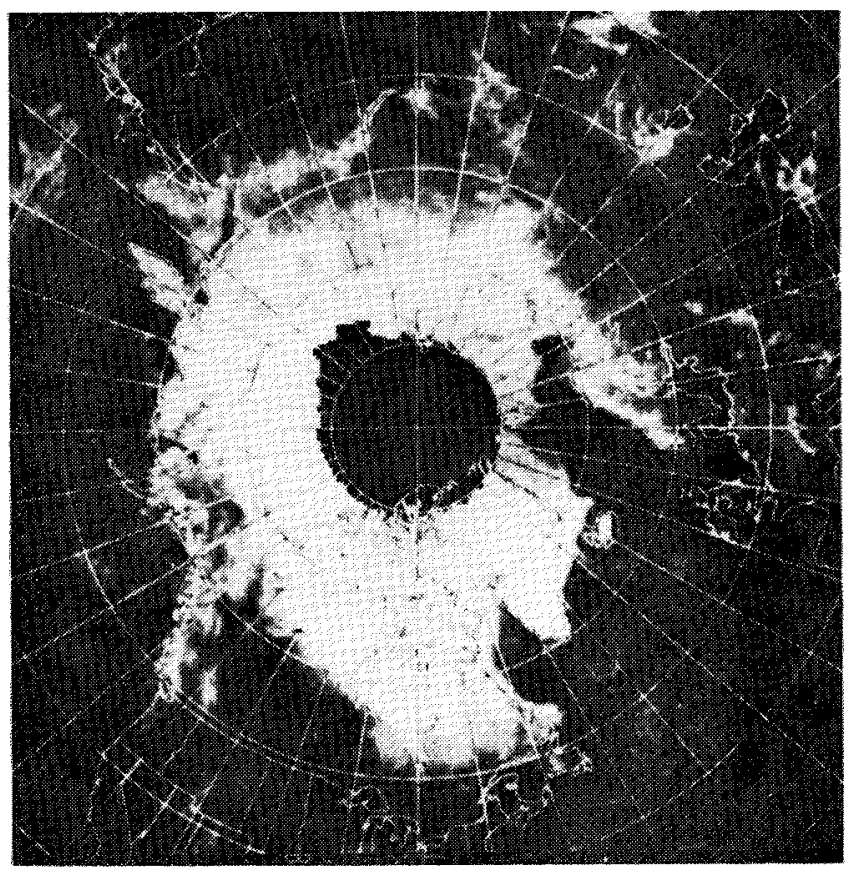

FIG. 2. Mesoscale 5-day Composite Minimum Brightness (CMB) chart derived from ESSA 9 digitized brightness data for 14 to 18 April 1969. Lack of sufficient polar illumination precluded mapping the area near the pole. 


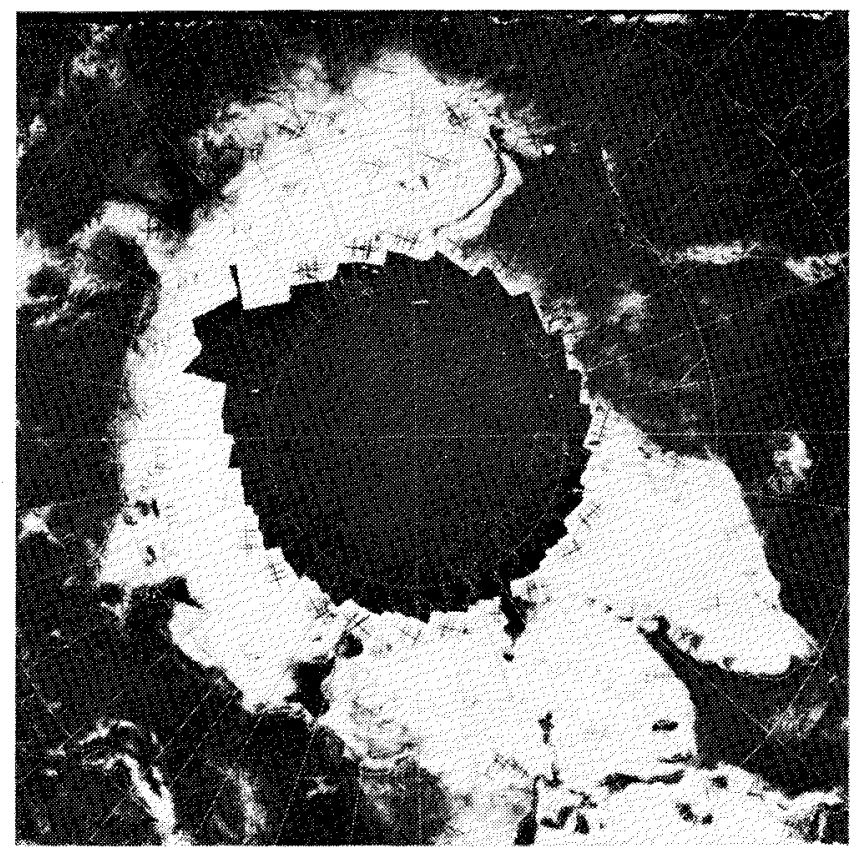

FIG. 3. Augmented resolution 10-day Composite Minimum Brightness (CMB) chart derived from ESSA 9 data for 24 May to 2 June 1970. Small crosses and corners are fiducial marks collected during the compositing process.

tion during the period. The minimums are displayed on a cathode ray film device in mapped form to create the CMB chart; latitude/longitude lines and geographic or political boundaries are added during this step.

The CMB chart in effect suppresses or filters relatively transitory cloud masses from the scene while retaining the imagery that corresponds to the more slowly changing snow and ice fields. Generally, natural surfaces other than snow or ice and clouds have rather low albedoes, and thus are retained in the CMB chart. Although extremely persistent cloud areas are not filtered by this method, they generally appear less bright and less coherent than snow fields and ice packs.

Although CMB imagery has proven to be an accurate and generally useful means of portraying the boundaries of compact or very close pack ice, especially when it has a snow cover, there is the possibility that more quantitative information about the sea ice can be extracted from the satellite data. There are two major problems that discourage quantitative use of the black-and-white, cathode ray tube photographs: first, the human eye cannot reliably distinguish more than about half of the 15 grey tones available in the imagery; secondly, variability in the development and printing of the photographs makes assessments of time variations from one compositing period to the next unreliable. Both of these problems can be circumvented by using a computer printout type of display (Fig. 4). The only drawback to this is the vast quantity of paper to be handled if a substantial geographical area is to be monitored.

Even when the vidicon data are presented in digitized form, there are still limitations to truly quantitative use (Schwalb and Gross 1969). All mapped data, 


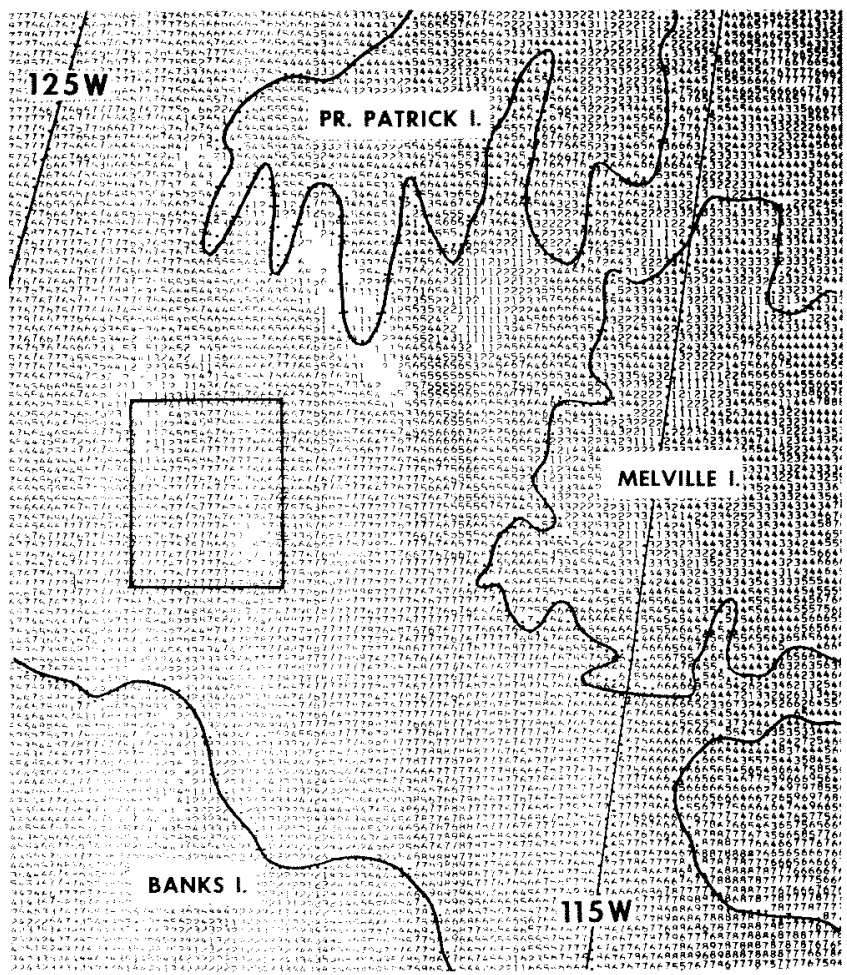

FIG. 4. Small portion of an augmented resolution Composite Minimum Brightness (CMB) printout derived from ESSA 9 data for 21 to 25 June 1969. The CMB values are printed out on a relative brightness scale of $0-14$, as follows: blank, 1 , $2,3, \ldots 9, A, B, C, D, E$

including the CMB values, have been corrected for nonuniformities in the camera lens and the face of the vidicon tube, i.e., the so-called vignette effect. All mapped data are also approximately normalized with respect to variations in solar zenith angle by a simple cosine correction. The ESSA Advanced Vidicon Camera System (AVCS) contains a 16-step grey-scale density filter illuminated by a flash tube each time a picture is taken. Although the relative brightnesses of each step in the grey wedge are monitored for evaluation of system response, and these data are qualitatively useful for display device settings, decisions on camera switching, etc., unknowns in the system (e.g., changes in flasher brightness with time or temperature) preclude rigorously quantitative applications.

\section{EXTERNAL CALIBRATION OF CMB VALUES}

Since no onboard or other internal calibration of the vidicon data was possible, attention turned to seeking a target area on Earth whose brightness was known, or was at least constant, within rather narrow limits. At the low end of the brightness range is the ocean surface in the absence of clouds and specular reflections (i.e. sunglint). At the high end are areas of deep snow, or ice and snow, unbroken by trees or other darker surfaces. The ice and snow of the central Greenland ice cap are probably ideal, situated as it is some 2,000 to 3,000 metres above sea level, for little or no melting očcurs there even in summer (Wilson 1969). Exami- 
nation of a large number of AVCS pictures taken over the Greenland area, as well as of 64-level brightness samples of digitized raw data (taken from the centre strip of individual frames), showed that clouds produced no systematic or even detectable change in the brightness of the ice cap over a 15-step brightness range. In fact, the only way to infer the presence of clouds over central Greenland is from continuity of a large-scale cloud pattern that extends over one or both of the adjacent ocean areas, or by slight shadow effects produced by a low sun and irregularities in the cloud coverage or heights.

To test the applicability of this sort of external calibration, which has been used in the construction of monthly and seasonal mean global charts of brightness (Taylor and Winston 1968) several areas in central Greenland between $65^{\circ} \mathrm{N}$. and $70^{\circ} \mathrm{N}$. were selected and samples of 5-day CMB values were taken from the computer printouts. The areas were $110 \mathrm{~km}$. on a side and, with data at a $5.5 \mathrm{~km}$. resolution, provided samples of 400 for each 5-day compositing period. Frequency distributions were constructed and means were computed for each of these samples. The histograms were highly peaked, the standard deviations being less than one brightness step from the mean. The sample means were quite conservative from the beginning of the period studied (17 May 1969) until 4 August 1969, ranging from 8.9 to 11.2 , with most of the values falling between 9.5 and 10.5. Beginning on 5 August and running through the end of the study period (13 September 1969), the sample means were even more stable, ranging from 13.1 to 13.9 , but they averaged about 3.5 brightness levels higher than before. Examination of grey-wedge and frame centre strip samples of raw digital data for the entire period confirmed the general stability of the camera system response, but gave no indication of the discontinuity in level that occurred near the first of August. The jump in brightness was found to have coincided with a change in the so-called "replacement tables." These tables are used in the data processing step that compresses the brightness range from 64 levels to 15, simultaneously incorporating the vignette correction and appropriate solar illumination normalizations.

To render the data sets internally consistent, all data were adjusted to the average of the 3 combined Greenland samples for the month of June 1969. The adjustment required was $\leq 1.0$ brightness level until August, but was -3.4 to -3.9 at the high end of the brightness range for the remainder of the study period. Since it was found that brightnesses at the low end of the range (i.e. over cloudfree ocean areas) jumped by only about 2 levels, appropriate adjustments for intermediate brightness levels were obtained by linear interpolation. Having made these adjustments, it was then possible to study and compare sample average brightnesses in different areas, and as a function of time, with some assurance that significant variations could be attributed to real changes in scene brightness and did not stem from vagaries in the camera or data processing system. This adjustment procedure does not, of course, remove the effects of residual cloudiness in the CMB data. This is of no particular consequence over the Greenland ice cap, but it is important elsewhere to distinguish between cloud and sea ice. This problem will be discussed in a subsequent section. 


\section{STUDY OF SEA ICE CONDITIONS IN FOUR ARCTIC AREAS}

Once having worked out the procedure for calibrating the CMB values with respect to the Greenland ice cap values, the computer printouts were used to obtain other samples of 400 for a variety of areas $110 \mathrm{~km}$. on a side in the North American Arctic (Fig. 5) and for the periods of mid-May to mid-September 1969 and April to to mid-June 1970. Sample means were computed and histograms were constructed. The southernmost group of areas studied included central Hudson Bay, M'Clintock Channel, Foxe Basin, and the northern part of Davis Strait. Much change in ice conditions occurred generally at these locations during the period studied. The second group of areas studied were near $75^{\circ} \mathrm{N}$.: the northern Beaufort Sea, an area just west of Banks Island, M'Clure Strait, and western and eastern Viscount Melville Sound. These areas were characterized mainly by compact or very close pack throughout the period. A third group of areas ranged in latitude from $68^{\circ} \mathrm{N}$. to $78^{\circ} \mathrm{N}$.; all were characterized by very open pack or ice-free waters throughout the season. These were the western Amundsen Gulf near Cape Bathurst, the Chukchi Sea near Cape Lisburne, Barrow Strait just east of Resolute, and Smith Sound between Greenland and Ellesmere Island.

The data for a representative member of each of the above groups are rep-

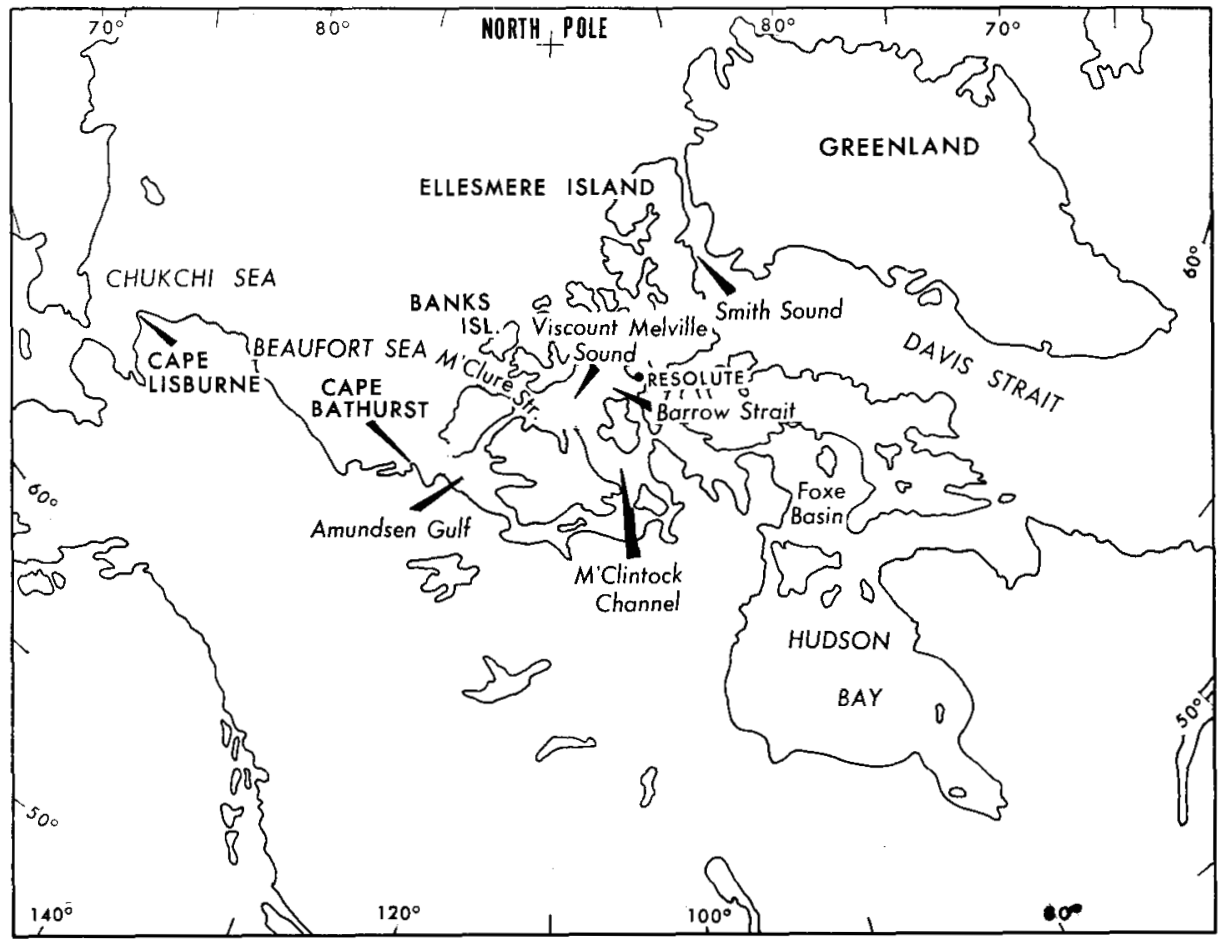

FIG. 5. Location map for the 4 areas discussed in the text: Melville Sound, Hudson Bay, Banks Island and Greenland. 
resented in graphic form in Fig. 6; data for one of the Greenland areas are also shown. Note that the adjusted brightness averages for the ice cap are consistently near 10 on the relative brightness or reflectivity scale of $0-14$. The sample brightnessess taken in western Viscount Melville Sound northeast of Banks Island initially are just as high as those for Greenland and remain between 9 and 10 through the first third of June. Thereafter the brightness drops rather rapidly to values between 6 and 7, remaining at this new level through early August. Throughout the remainder of the study period ending in mid-September the brightness in Melville Sound fluctuated between about 3 and 5. According to the BIRDS EYE 4-69 Arctic Ocean ice reconnaissance mission (Jerdon and Freeman 1969), which passed over this part of Melville Sound on 3 June and again on 10 June, the following ice conditions were observed: $8 / 8$ total concentration of fast ice, 5/8-6/8 multiyear and 3/8-2/8 thick first year; no openings, no melting. BIRDS EYE mission 5-69 (Koester and Freeman 1970), which reconnoitred this area again on $28 \mathrm{July}$, reported the following: $8 / 8$ total concentration; $3 / 8$ multiyear, $3 / 8$ second year, $2 / 8$ thick first year; fractures, many puddles, and a few thaw holes. BIRDS EYE data were not available for August or September in the Melville Sound area, but weekly ice charts issued by Canada Department of Transport, Meteorological Branch, for August show 10/10-2/10 multiyear, 5/10$4 / 10$ second year, and $4 / 10$ or less first year. (Ice concentration is given in tenths of coverage in the Canadian ice charts and in eighths (oktas) in the BIRDS EYE reports. Although it would make for somewhat easier reading, it was decided that conversion to a single set of units was not warranted.) Puddles, 3/10 of them frozen, were reported. For the first half of September, the principal change in ice conditions was a decrease to no first year ice and the first appearance of new ice. There was also a trend towards freezing of puddles and the occurrence of snow cover.

Meteorological observations from Mould Bay on Prince Patrick Island and Resolute on Cornwallis Island show that the Melville Sound area experienced below to well-below freezing temperatures and fresh snowfalls as late as the second week in June. The remainder of the summer was characterized by temperatures at or above freezing, mostly $35^{\circ} \mathrm{F}$. to $45^{\circ} \mathrm{F}$. with the first freezing and sub-freezing temperatures and new snow reported the last week in August and again in the second week of September. The temporary interruptions in the generally downward trend of brightness after the middle of June can be attributed to persistent cloudiness generally associated with storm centres (e.g. towards the latter part of July and early in August) or to fresh snow, such as at the end of August.

In summary, western Melville Sound was characterized by high brightness values (equal to or approaching Greenland values) during the early part of the period when the ice pack was snow covered. Brightnesses decreased by about 30 per cent when the snow melted and puddles developed in late June and persisted through July. The brightness level diminished somewhat more in late August through mid-September as fractures and thaw holes appeared and some of the first-year ice melted. Some of the small peaks interrupting the general 
downward trend of brightness are associated with stormy periods when persistent cloudiness was not completely filtered by the compositing technique. The upturn in mid-September could also be related to the reported reappearance of some snow cover on the ice.

Central Hudson Bay (Fig. 5) was characterized by moderately high brightness averages, near 8 , through mid-June, after which a remarkably steady decrease set in, with values reaching zero by the first of August. The brightness remained at or very near zero for the remainder of the study period. No BIRDS EYE data were taken over or near this area, so all comparisons are with the Canadian weekly ice charts, the earliest available being for the week ending 18 June. Concentrations were reported as $8 / 10$ to $\leq 9 / 10$, all first year ice, from 18 June until mid-July, with $1 / 10-2 / 10$ puddles and $1 / 10-2 / 10$ thaw holes first being reported the last week of June. Through the month of July, the total concentration decreased to $7 / 10$, the fraction given as "medium floe or greater" steadily diminished from $5 / 10-10 / 10$ to $2 / 10$, and the percentage coverage of puddles increased to $5 / 10$. In the first week of August there was an abrupt decrease in total concentration to $2 / 10$ to $5 / 10$, and by mid-August ice-free conditions were reported in central Hudson Bay.

The Hudson Bay brightnesses ran two brightness levels lower than Melville Sound or the Greenland ice cap in May and the first half of June, suggesting lack of an extensive snow cover on the Hudson Bay ice pack. Unfortunately, the author was unable to find data that would conclusively establish the presence or absence of a snow cover in this area. Some indication is given by the satellite data for April and the first half of May of 1970, however, where it may be noted that $\mathrm{CMB}$ values for both Melville Sound and Hudson Bay were near 10. The nearest weather station generally upwind of the Hudson Bay site is Churchill, Manitoba. The first thawing period of any consequence at Churchill occurred from 21 to 24 April, with temperatures reaching the mid-forties on the $23 \mathrm{rd}$. Thereafter, until essentially uninterrupted thawing conditions set in on the first of June, temperatures were subfreezing except on 5-6, 14 and 26 May. Although two of the brief thawing spells in May were accompanied by rain, snow was reported as late as the last week in May.

In summary, the trend of adjusted brightness averages in central Hudson Bay appears to correlate well with the melting and decreasing concentrations of ice reported in that area. Evidence of snow cover extent on the ice is inconclusive.

The final sampling area represented in Fig. 5 is southwest of Banks Island near Cape Bathurst, which is representative of areas that tend to remain ice-free throughout the season. The highest brightness averages here ranged between 2 and 3 , but much of the time the values were 1 or less. The high values in May were the result of the presence of shorefast ice along the east side of Cape Bathurst and extending into the southwest corner of the sampling area. Had the sampling area been less than $40 \mathrm{~km}$. to the northeast the adjusted brightness averages in May would have been well under 1. The BIRDS EYE flight passed over this area on 3 and 10 June and on 29 July; in all cases the ice concentrations were reported as zero or $<1 / 8$. The weekly Canadian ice charts for 18 July 
through 13 September reported open water in this area southwest of Banks Island, with one exception. The chart for the week ending 29 August showed a narrow finger of $3 / 10$ ice concentration within the sampling area.

Meteorological data for Cape Parry on the Canadian Coast, and Sachs Harbour on Banks Island, indicate that persistent cloudiness, mostly associated with nearby storm centres or fronts, could account for the low-intensity CMB brightness peaks of about level 2 that occurred in late May, mid-July and mid-August.

In summary, ice-free conditions in this area were characterized by brightness averages generally $\leq 1 / 10$ of those typical of ice cap or snow covered compact or very close pack ice. Occasional small increases in brightness were associated with periods of unusually persistent cloudiness.

\section{COMPARISONS WITH 1970 DATA}

A relatively short period of 1970 data, 5 April to 17 June, is available for comparison purposes; the CMB values for this period, adjusted in the same way as the 1969 data sample, are graphed in the right-hand portion of Fig. 6. The Melville Sound area was characterized by brightnesses near 10 until past midMay when they decreased to about 8 . There are corroborative data for 13 April from the BIRDS EYE 1-70 mission (Freeman and Tucker 1970) in this area: the aerial observer reported total ice concentrations of $8 / 8$ (4/8 multiyear, $2 / 8$ second year, $2 / 8$ thick first year) with no openings and no melting. About a month later, on 14 May, Canadian aerial surveys reported 10/10 total concentration (2/10 multiyear, $2 / 10$ second year, and $6 / 10$ thick first year), all medium floe or larger, with 10/10 snow cover. The United Kingdom Ice Charts (Great Britain Meteorological Office 1970) and Canadian Ice Charts for the period (which, it should be noted, are based partially on photo-interpretation of satellite pictures) show 10/10 concentration throughout the entire period.

One must depend upon deductions from thinly scattered meteorological observations to confirm the hypothesis that the drop in brightness occurring here late in May was associated with a sharply decreased extent of snow cover on the ice. Maximum daily surface air temperatures reported in this area up to about 18 May were $15^{\circ} \mathrm{F}$. or less, after which a slow moderating trend set in under largely cloudfree skies. By the 24 th, and persisting through the $26 \mathrm{th}$, temperatures rose to between $30^{\circ} \mathrm{F}$. and $40^{\circ} \mathrm{F}$. After a couple of days of temperatures between about $25^{\circ} \mathrm{F}$. and $30^{\circ} \mathrm{F}$, they rose again from $30^{\circ} \mathrm{F}$. to $35^{\circ} \mathrm{F}$. on $31 \mathrm{May}$ and 1 June. With the exception of another period from 8 to 12 June, when highest temperatures were about $35^{\circ} \mathrm{F}$. on 4 of the 5 days, maximum daily temperatures were $25^{\circ} \mathrm{F}$. to $30^{\circ} \mathrm{F}$. throughout the remainder of the period. Skies were partly cloudy to mostly cloudy throughout the first half of June.

Although one cannot reach a definitive conclusion, the weather conditions just described are consistent with thawing of the snow cover beginning late in May. The weak intensity of the warming and the relatively brief periods of abovefreezing air temperatures, however, would not appear to have been conducive to much puddling. 


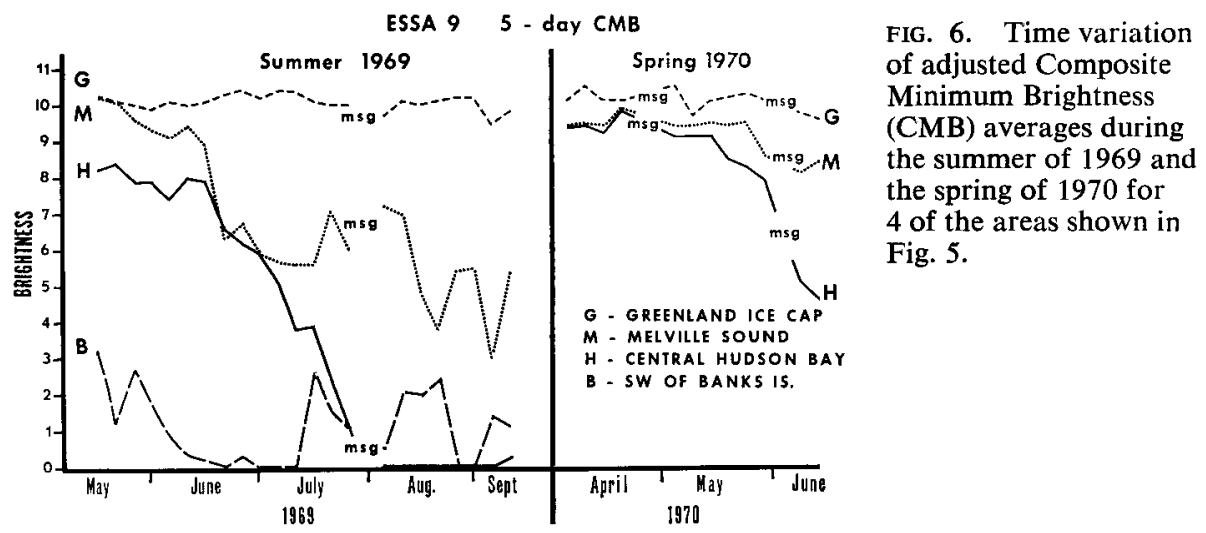

For the central Hudson Bay area, Fig. 6 shows a fairly rapid and continuous drop in brightness, from values that had been continuously near 10 since the first of April, commencing about the end of the period. The only independent observations known to the author are from a Canadian aerial ice mission on 30 April. The closest approach of this flight to area " $\mathrm{H}^{\prime}$ " $\left(59^{\circ} 5^{\prime} \mathrm{N}\right.$., $84^{\circ} 5^{\prime} \mathrm{W}$.) was $60^{\circ} 5^{\prime} \mathrm{N}$., $83^{\circ} \mathrm{W}$., or about $140 \mathrm{~km}$. Ice conditions reported here were: $9 / 10$ plus total concentration ( $9 / 10$ thick first year and 1/10 nilas), the first year ice consisting of medium floe or larger, and $9 / 10$ snow cover. Ice conditions in this portion of Hudson Bay for the remainder of the period, as given by the United Kingdom and Canadian ice charts, would indicate little change from those observed at the end of April, viz. total ice concentrations of $7 / 10$ to $9 / 10$ plus. These analyses, however, appear to be based primarily on extrapolation combined with interpretation of satellite imagery. Hence, they are not completely independent information, nor do they contain any information about extent of snow cover or puddling.

The decrease in brightness at " $\mathrm{H}$ " to levels of 5 or less by mid-June strongly suggests that no snow cover was present and puddling had become extensive. Some inferences about this can be made from meteorological charts and satellite cloud imagery for the period. Maximum daily surface air temperatures on the shores of Hudson Bay upwind of " $\mathrm{H}$ " were well below freezing through 5 May and near or somewhat below freezing through the 12th. Marked warming set in on the $13 \mathrm{th}$, temperatures reaching $50^{\circ} \mathrm{F}$. to $55^{\circ} \mathrm{F}$. the next day on the west shore as winds picked up from the southwest. On 16 May temperatures lowered to $30^{\circ} \mathrm{F}$. to $35^{\circ} \mathrm{F}$. with rain. With the exception of temperatures near $40^{\circ} \mathrm{F}$. again on the 19th, temperatures remained in the 20's through the 26th. After several nearly cloudfree days of increasing southwest winds and warming, temperatures rose as high as the 50s and 60s on 28 and 29 May.

Maximum daily temperatures on the upwind shores of Hudson Bay remained above freezing throughout the remainder of the period (i.e., through 17 June), with strong southwesterly winds again bringing western shore temperatures into $50 \mathrm{~s}, 60 \mathrm{~s}$ and even 70 s on 2 to 5 and 12 to 13 June. Skies were mostly cloudfree during the period. Clouds became much more readily distinguishable from the ice in June because of the greatly lessened reflectance of the ice surface. 
In summation, the weather conditions just described are consistent with rapid disappearance of the snow cover from the ice pack commencing in mid-May, followed by continued and intensified thawing conditions during the first half of June.

\section{CONCLUSIONS}

It has been demonstrated that quantitative application can be made of the satellite vidicon data, particularly the digitized 5-day composite minimum brightness (CMB) values, for diagnosis of sea ice conditions. These data, however, must first be externally calibrated with respect to areas of Earth's surface having an essentially constant brightness, such as the Greenland ice cap and a cloudless ocean.

Examination of adjusted CMB averages, together with ice reconnaissance data, ice charts, and meteorological data, for a number of arctic areas during spring and summer periods in 1969 and 1970 indicates that characteristic brightness values are associated with different ice pack concentrations and conditions. These relationships are summarized in Table 1. Residual cloudiness in the CMB charts presents a minor problem at the lower end of the brightness range in that areas of very open pack or ice-free areas may sometimes have brightness values of 2 to 4 . This could lead to underestimations of these ice conditions and overestimations of open pack concentrations. It should also be noted that thin new ice, which has a very low reflectance, cannot be distinguished from very open pack or ice-free waters.

The results shown in Table 1 were compared with the relation between ice cover, puddle cover, and surface albedo proposed by Hansen (1961), and the agreement was excellent. Hansen's results were based on airborne radiation measurements over parts of the Beaufort and Chukchi seas and on albedo

TABLE 1. Summary of association between ice concentration/condition and adjustment Composite Minimum Brightness (CMB) averages.

\begin{tabular}{|c|c|c|c|}
\hline Category & Adjusted $C M B$ average & Ice concentration & Ice condition \\
\hline 1 & $9-10$ & $\begin{array}{l}\text { Compact or } \\
\text { very close pack } \\
(10 / 10-9 / 10)\end{array}$ & $\begin{array}{l}\text { Snow covered } \\
(>7 / 10)\end{array}$ \\
\hline 2 & $7-8$ & $\begin{array}{l}\text { Compact or } \\
\text { very close pack } \\
(10 / 10-9 / 10)\end{array}$ & $\begin{array}{c}\text { Snow free }(<3 / 10) \\
\text { little or no } \\
\text { puddling }(<1 / 10)\end{array}$ \\
\hline 2 & $5-6$ & $\begin{array}{l}\text { Very close or } \\
\text { close pack } \\
(9 / 10-7 / 10)\end{array}$ & $\begin{array}{c}\text { Some puddles and } \\
\text { thaw holes } \\
(1 / 10-3 / 10)\end{array}$ \\
\hline 4 & $2-4$ & $\begin{array}{l}\text { Open pack } \\
(6 / 10-4 / 10)\end{array}$ & $\begin{array}{l}\text { Much puddling } \\
(>3 / 10) \text { and } \\
\text { rotten ice }\end{array}$ \\
\hline 5 & $0-1$ & $\begin{array}{c}\text { Very open pack } \\
(3 / 10-1 / 10) \\
\text { or ice free waters }\end{array}$ & - \\
\hline
\end{tabular}


measurements for melt-water pools and clean, melting sea ice reported by Briazgin (1959), Untersteiner (1961), and others. More recent measurements, which were obtained by suspending radiometers $15 \mathrm{~m}$. above the ice between two high towers, have been reported by Langleben (1968). Compared with Hansen's, Langleben's values show a sharper dropoff in albedo as the snow cover disappears and puddle cover increases. Since the Langleben measurements were restricted to $10 / 10$ ice concentration, no strict comparison can be made with the results given in Table 1 . Qualitatively, however, the results are quite consistent.

Untersteiner and Maykut (1969) and others have stated that the surface albedo and its variations are probably the most important regional factor affecting the heat and mass budgets of the Arctic Basin. Since the adjusted CMB values derived from satellite vidicon data appear to be highly correlated with albedoes obtained over sea ice by other means, the technique presented in this paper presents the promise of a powerful tool for use by sea ice researchers and forecasters. CMB charts, such as those shown in Figs. 2 and 3, can be readily transformed into sea ice charts by displaying the brightness values, after adjustment, in 5 grey tones corresponding to the 5 classes of sea ice conditions given in Table 1 .

Scanning radiometer data, now available from satellites in both the visible and infrared portions of the spectrum, can be used to monitor sea ice during the polar night (Barnes et al. 1970), and the additional thermal information should prove useful, for example, in delineating areas of thin ice cover.

\section{ACKNOWLEDGEMENTS}

I should like to acknowledge the technical assistance of the following: Arthur Booth, Julia Hart, Simon Roman and Maurice Baliles. This research was supported in part by NASA's Earth Resources Survey Program.

\section{REFERENCES}

ABER, P. G. and E. vowINCKel. 1972. Evaluation of North Water spring ice cover from satellite photographs. Arctic, 25: 263-71.

BARNES, J. C., D. T. CHANG and J. H. WILlAND. 1970. Improved techniques for mapping sea ice from satellite infrared data. Final Report, Contract E-67-70(N), Allied Research Associates, Concord, Mass., 95 pp.

BOoTH, A. L. and V. R. TAYLOR. 1969. Meso-scale archive and computer products of digitized video data from ESSA satellites. Bulletin of American Meteorological Society, 50: 431-38.

Bowley, C. J. 1969. Use of Nimbus APT to determine the rate of ice disintegration and dispersion in Hudson Bay. Technical Report No. 8, Contract NAS 5-10343, Allied Research Associates, Concord, Mass., 39 pp.

BRISTOR, C. L., W. M. CALliCOTT and R. W. BRADFORD. 1966. Operational processing in satellite cloud pictures by computer. Monthly Weather Review, 94: 515-27.

BRIAZGIN, N. N. 1959. The problem of the albedo on the surface of drifting ice. Problemy Arktiki $i$ Antarktiki No. 1 (Translated for Geophys. Research Directorate on Contract AF-19(604)6113), pp. 33-39.

CANADA METEOROLOGICAL BRANCH. 1969. Ice summary and analysis, Hudson Bay and approaches, 1966 . Toronto: Canada Department of Transport. 
FREEMAN, R. F. and R. L. TUCKER. 1970. BIRDS EYE 1-70, 17-26 April 1970. Informal Report IR No. 70-55, U.S. Naval Oceanographic Office, 108 pp.

GREAT BRITAIN METEORological ofFICE. United Kingdom ice chart. Great Britain Meteorological Office, Marine Division (issued at 10-day intervals and compiled monthly).

HANSEN, K. J. 1961. The albedo of sea ice and ice islands in the Arctic Ocean basin. Arctic, 14: $188-96$.

JERDON, H. P. and R. F. FREEMAN. 1969. BIRDS EYE 4-69, 26 May-15 June 1969. Informal Report IR No. 67-79, U.S. Naval Oceanographic Office, 211 pp.

KOESTER, R. W. and R. F. FReEman. 1970. BIRDS EYE 5-69, 18 July-5 August 1969. Informal Report IR No. 70-2, U.S. Naval Oceanographic Office, 155 pp.

LANGLEBEN, M. P. 1968. Albedo measurements of an arctic ice cover from high towers. Journal of Glaciology, 7: 289-97.

MCCLAIN, E. P. and D. R. BAKER. 1969. Experimental large-scale snow and ice mapping with satellite composite minimum brightness charts. ESSA Technical Memorandum NESCTM 12, U.S. Department of Commerce, $16 \mathrm{pp}$.

MCCLAIN, E. P. and M. D. BaLILES. 1971. Sea ice surveillance from Earth satellites. Mariners Weather Log, 15: 1-4.

POPHAM, R. W. and R. E. SAMUELSON. 1965. Polar exploration with Nimbus meteorological satellite. Arctic, 18: 246-55.

POTOCSKY, G. J. 1968. Use of satellite photographs to supplement aerial ice information. Informal Report No. 68-72, U.S. Naval Oceanographic Office, 13 pp.

SCHWALB, A. and J. GRoss. 1969. Vidicon data limitations. ESSA Technical Memorandum NESCTM 17, U.S. Department of Commerce, $22 \mathrm{pp}$.

TAYLOR, V. R. and J. S. WINSTON. 1968. Monthly and seasonal mean global charts of brightness from ESSA 3 and ESSA 5 digitized pictures, February 1967-February 1968. ESS A Technical Report NESC 46, U.S. Department of Commerce, 9 pp., 17 charts.

UNTERSTEINER, N. 1961. On the mass and heat budget of Arctic sea ice. Archiv für Meteorologie, Geophysik, und Bioklimatologie, Ser. A., 2: 151-82.

UNTERSTEINER, N. and G. A. MAYKUT. 1969. Numerical prediction of the thermodynamic response of Arctic sea ice to environmental changes. Memorandum RM-6093-PR, Contract No. F 44620-67-C-0045, Rand Corporation, 173 pp.

VASIL'EV, K. P. 1968. Use of meteorological-satellite data as a navigation aid. Trudy No. 36, Problems of Satellite Meteorology (Editors: I. P. Vetlov and G. I. Morskoi), Hydrometeorological Research Center of the USSR (Translation TT 70-50001 for ESSA and NSF, 1970, pp. 46-57).

WARK, D. Q. and R. W. POPHAM. 1962. The development of satellite ice surveillance techniques. Proceedings of First International Symposium on Rocket and Satellite Meteorology, pp. $415-18$.

WILson, c. 1969. Climatology of the cold regions, Northern Hemisphere II. Cold Regions Science \& Engineering Monograph I-A3b, U.S. Army Cold Regions Research \& Engineering Laboratory, $158 \mathrm{pp}$. 